Christine Leahy

christine.leahy@ntu.ac.uk

Nottingham Trent University, Department of Modern Languages, (Newton 520),

Burton Street, Nottingham, NG1 4BU

\title{
Researching language learning processes in open CALL settings for advanced learners
}

Abstract

This article reports on a project (electronic role-play) run at Nottingham Trent

University. It investigates how knowledge can be constructed collaboratively in an open setting based on computer-mediated communication (CMC) and the internet as primary source for material.

The analysis will concentrate on evidence of (1) focus on language form and (2) acquisition of content. Furthermore, it reports about observations made regarding the way in which students utilize the electronic environment during the learning process, namely (3) the flow of information within an open CALL framework and (4) the nonlinear composition of text.

\section{Introduction}

Computer-assisted language learning is beginning to establish itself as a research field in its own right. Several systematic presentations of the developments in CAL/L came on the market during the last 5 years. For example, Delcloque (2001) outlines trends in the evolution of computer-assisted learning (CAL), but puts greater emphasis on the technical side of the development. Levy (1997) presents an overview of the development of computer-assisted language learning and he continues with a later publication which attempts to describe and categorise CALL research as represented in international publications during the year 1999 (Levy: 2000). Warschauer and Kern (2000) give an overview of the development from the perspective of pedagogy and language learning theory, while Chapelle (2001) presents "foundations for teaching, testing and research" (subtitle) in CALL.

Since its early application (based on stimulus -response tasks underpinned by behaviourism) CALL has undergone changes which are closely related to (a) the theoretical framework which informed the CALL authors and (b) the technical possibilities and availability which increased with time. Recent developments show 
CAL/L based more on communicative methods (Warschauer and Kern, 2000) and cooperative learning (constructivism or constructionism, Papert,1993). The availability of the internet allows easy access to primary material as well as enabling students to become authors on the world wide web and thereby adding a very different quality to the language learning experience (Warschauer, 1999). Being able to reach a potentially vast audience outside the classroom can have an important impact on student motivation and the quality of the produced work. Warschauer (2001) describes how the internet was used in a Hawaiian language revitalisation project which transformed the internet from a place for research purposes to a place where students could express their identity, and thereby empowering them.

The increased availability of the internet and computers in general is having a profound impact on societies and literacies ${ }^{1}$ around the world (e.g., Ess, 1996, 2001; Murray, 2000; Warschauer, 1999, 2001). Symptomatic of this impact is the shift in teaching and learning approaches towards e-learning ${ }^{2}$.

However, more research into CALL is needed (Chambers, 2001; Davies, 2001; Levy, 2001) particularly into the area of evaluation in the context of second language acquisition (Chapelle, 1997, 2001). In the past, evaluation of CALL tended to focus on comparative studies ${ }^{3}$, typically based on what Chapelle (2000: 211) calls the "myth of [the] 'CALL method'", i.e. comparisons between those subjects using computers and those not. This research focuses on the outcome alone, and not on the variables of the learning process, e.g., teacher instruction and learner variables. It also does not take full account of the different types of activities (e.g., based on drill exercises or individual production of text) grouped under the term CALL.

There is a need to evaluate CALL from the perspectives of computer-assisted learning processes and outcomes. More studies are needed which look closely at the humanhuman and human-machine processes and interactions when students work with a

\footnotetext{
${ }^{1}$ E.g., Ess (1996, 2001). For a discussion of the term literacies (plural) see e.g., Warschauer (1999).

${ }^{2}$ E-learning is understood here as a general term which implies the use of electronic transmission of information from the teaching institution to the learning student and vice versa. E-learning can be interpreted as distant learning or as the use of technology-enhanced learning which can take place locally inside or outside the teaching situation, i.e., in class time or as directed or independent learning. In all cases, the computer is the medium and the constituent part where learning processes take place. ${ }^{3}$ Levy (2001) develops a general typology of comparative studies based on his survey of CALL literature published during 1999 and 2000 (Levy 2000).
} 
computer. This article reports about some of the processes observed while students are engaged in a CALL task.

For the second issue, CALL outcomes, Chapelle (2001:55) names 6 criteria for appropriate CALL task design, namely language learning potential, learner fitness, meaning focus, authenticity, positive impact and practicality. The task of the electronic role-play project reported on here fulfils 5 of the criteria named above, but does not guide specific focus on language form. The learner-centred approach gives students opportunities to influence, or indeed determine, most details of the project. Focus on meaning is placed in the foreground of the project, but not grammatical issues or syntactical concerns.

Chapelle (2001:58) points out that "language learning potential should be considered the most critical for CALL activities." This would involve" beneficial focus on form" (55). However, this article argues that activities like electronic role-plays can be equally beneficial CALL activities, even though focus on form does not appear in the foreground. For advanced language learners who already can communicate successfully in higher-order situations, e.g., in subject-specific contexts, L2 practice in relevant authentic contexts is equally important. Focus on language form develops through the process of the project and may differ from group to group, or indeed from individual student to student, as will be shown later. Here the role of the tutor and the follow-up activities can be crucial, because individual language learning needs can be addressed.

\section{The project}

The following represents preliminary results of the electronic role-play which takes place within a subject-specific context.

The subjects are BA European Business students and advanced learners of German, who entered their university degree course with an A-level German qualification. At the time the project takes place, the students are in their $4^{\text {th }}$ year of study and have spent the previous year in Germany. While abroad, their time was equally divided between studying at a German university and working on placement in a company.

The project is a meaning-focused activity, largely learner-controlled and processoriented. It is based on an electronic role-play, which takes place during class time during a 4-week period. The electronic role-play consists of a collaborative, problem- 
solving task conducted in the target language (see figure 1). The project simulates the following scenario: A British company ${ }^{4}$ wants to launch a new product in the East German market (Neue Bundesländer). It communicates with a German market research company (another group) which looks at the feasibility of launching that product in Germany. Three other groups research the internet and provide further background information, either on request by group 1 or through their own initiative. The aim is to develop a market research strategy and marketing strategy.

\begin{tabular}{|c|c|c|c|c|c|c|c|c|c|c|}
\hline task & $\rightarrow$ & $\begin{array}{l}\text { formulation } \\
\text { of question } \\
\text { of each } \\
\text { group's } \\
\text { research }\end{array}$ & $\rightarrow$ & $\begin{array}{l}\text { internet } \\
\text { search } \\
\text { (if } \\
\text { appro- } \\
\text { priate) }\end{array}$ & $\rightarrow$ & $\begin{array}{l}\text { processing } \\
\text { information }\end{array}$ & $\rightarrow$ & $\begin{array}{l}\text { producti } \\
\text { on of } \\
\text { output } \\
\text { (in form } \\
\text { of ... } \rightarrow \text { ) }\end{array}$ & $\rightarrow$ & $\begin{array}{l}\text {-questions to } \\
\text { be researched } \\
\text {-email messa. } \\
\text { between } \\
\text { groups } \\
\text {-oral present. } \\
\text { (group) } \\
\text {-oral } \\
\text { interaction } \\
\text { (transcribed), } \\
\text { writ.summary } \\
\text { (individual) }\end{array}$ \\
\hline
\end{tabular}

(Figure 1, sequence of activities for each group)

Primary information is accessed on the web, selective information is used to solve the given problem. In groups, students take on different roles and research different aspects which are to be synthesised to come to a solution for the problem. Any communication between the groups is to be conducted via email. Collaboration within each group is also recorded on tape. Results are presented orally by the different groups. During the final week, students write individual summaries of the results and evaluate the project, as well as their own and their fellow students' performance. A final discussion about the learning experience is recorded on tape.

\footnotetext{
${ }^{4}=$ group $1-$ this article focuses on this group only.
} 
The market research-oriented task has been tested for 4 consecutive years ${ }^{5}$. It is sufficiently open to allow students to make their own specific choices following their interests. Each year, students chose a different product to research and used different research patterns.

Amongst others, the following skills are practised:

- $\quad$ surface reading

- reading in depth

- to process information following specific questions (as formulated by students themselves),

- to summarize and modify information,

- to produce specific answers to the questions and task in general,

- to produce specific answers to the questions of fellow students,

- to prepare an oral presentation,

- to write a critical appraisal of the group work.

\section{Research Method}

\subsection{Discussion of Research Method}

In order to investigate how (and if) learning takes place in this open collaborative setting, it was envisaged to track the students' interaction with the computer. Specific hypotheses were not formulated in advance, this was felt would narrow the approach considerably. Instead, it was envisaged to create a framework which would allow crucial moments to show up, e.g., a comparison between the primary information on the web and the results presented by the students should show whether the web information was plagiarised or the language output was modified.

A commercial tracking software (STARR) was tested in advance to see, whether it would log student activity while they were engaged in working with the machine. The aims were to track

* accessed information on the web,

* mouse movements like copying and pasting, including the information copied,

* keystrokes which allow for a readable text,

${ }^{5}$ see Leahy, C. (2001); small adjustment were made this year in order to facilitate more data collection. 
* applications in use, e.g., word document, email, internet + URL and time.

STARR does log all URLs and shows up keystrokes. However, it does not show which information is copied from the web and pasted into a word document.

Furthermore, if one rectifies a mistake while typing, the keystroke sequence includes the incorrect letter, the backspace delete symbol and the correct letter making the keystroke log difficult to read if someone types with many errors. It would be difficult to match up the text that is captured to the text within a document and the text on the web. In other words, the important moves cannot be tracked in a manageable manner. On the other hand STARR does show up confidential information, e.g., the password for email access. Tracking with this software would therefore open ethical problems and had to be abandoned.

Several computer specialists were asked for help, e.g., colleagues in the computing department and ICT support at Nottingham Trent University, the founder of a software design company, Alan Cooper, and specialists in CALL, e.g., Paul Brett, Graham Davies, Vance Stevens, Mark Warschauer as well as colleagues using the IATEFL list ${ }^{6}$. The replies received suggest that such tracking software does not exist. Since tracking software could not be employed, it was decided to use more conventional methods which can be handled by one person ${ }^{7}$. The subject-specific task encourages students to incorporate their background knowledge in order to solve the task. Students also decide on the product they want to research. In order to eliminate variables and to create a point against which the outcome can be measured, students formulate specific questions they want to research at the beginning of the project. It is assumed that these initial questions are a representation of the knowledge students do not have at the beginning of the project. Since the oral presentation and written summary can be compared to the initial questions, the answers can therefore indicate (content) knowledge being gained.

\footnotetext{
${ }^{6}$ I would like to thank my colleague Elaine Arici who kindly posted the request for help for me. I am not a teacher for English and am therefore not a member of the list.

${ }^{7}$ This project received a small amount of financial support from the Centre of Academic Practice at Nottingham Trent University, which was intended for support in transcribing the oral interaction, and for which I am very grateful. I would also like to thank Trevor Pull, Resource and IT Manager, who retrieved the students' bookmarks at the end of the sessions. However, there was no funding available to support any other assistance in form of e.g., observers, teaching relief or further technical support.
} 
Furthermore, it was assumed that a comparison between the emails exchanged and the texts produced (oral interaction during group work phases as well as text presentations (oral + written)) may indicate shifts in the line of enquiry and help mapping the students' paths while working with the machine.

Oral interaction in each group was recorded during each session. It was envisaged that the transcripts would allow insights into the working processes the students were engaged in. For example, the transcripts could possibly highlight where problems occurred, where students hesitated, negotiated meaning, clarified problems, coached each other. In conjunction with the email exchanges it was hoped to help shedding light on the process of mapping the students' path of work.

The following corpora were retrieved:

- websites which were consulted

- email communication between student groups

- transcript of oral interaction while involved in the task

- oral presentations, transcript (powerpoint presentations, optional)

- critical written appraisal + summary of project work

- transcript of final discussion.

\subsection{Critique of methodological approach}

It is probably impossible to develop an all-encompassing methodological approach. Several interesting lines of enquiry could not be followed through. Some variables of the learning process could not be eliminated or studied in detail and therefore would make generalisations of the results difficult. For example, learner differences and the level of student autonomy were not analysed. Furthermore, it would be a near impossibility to determine which knowledge (content and language) students had before the start of the project . In order to overcome this last point, an attempt was made to come to a methodological approach by asking students to formulate their questions for enquiry in advance. Once these questions were formulated, this provides a form of measurement against which the outcome can be compared.

There are further difficulties inherent in this approach: The computer clocks in the university computer rooms are not all set to the precise real time. The chronological 
order of email exchanges between groups can therefore get corrupted. Individual student comments may be difficult to transcribe due to background noises of student interactions in other groups, computer and cassette recorder humming and quiet student talk in the recorded groups. Furthermore, not all students feel comfortable with the recording of their group interaction. Some groups talked very little, but would have probably spoken more had they not been recorded (as was observed during group work in the traditional classroom).

In order to track the web sites used students were asked to set bookmarks. The retrieval of bookmarks of favourites of internet sites relies on students' diligent cooperation. It seems an unreliable approach, because students can forget, or do not want to disclose all sites used or consider some sites not relevant to book-mark.

\section{Preliminary findings}

The following findings refer mainly to one pair of students (group 1) who took the role to represent a company in Nottingham which is about to launch its product on to the German market, concentrating on the regions of the so called Neue Bundesländer. The corpora used here consist of 3 session transcripts, each with a length between approximately 5200 and 5900 words. During each session between 3-12 emails with short messages were sent by this group, many more were received from the other groups. The students' written summaries of the project's findings and critical evaluation had a length of 728 (stud. 1) and 784 (stud. 2) words. The transcript of the final discussion by all groups about the project has an approximate length of 2160 words.

This paper focuses on 4 findings: (1) how the initial students' questions (their research questions) were answered at the end of the project, (2) an example how students solve grammatical problems collaboratively, (3) the flow of information within this open CALL framework, and (4) the non-linear composition of text.

\subsection{Group 1- questions to be answered during the project}

After an initial brainstorming session, student 1 and 2 decided that the chosen product was to be Christmas Pudding. They considered which information would be necessary in order to develop a marketing strategy and formulate their initial questions (see table 1 below). At the end of the project the group delivered a 
presentation of their findings (week 3) and each student wrote an individual summary during week 4. The answers to the initial questions can be found below (table 1). The initial questions for enquiry were sent to the different groups to be researched on the internet. As the reported results show, the different groups' internet searches did not produce all the specific answers, group 1 was hoping for. For example, questions regarding the market share of competitors could not be answered. However, through an email enquiry provided by one of the support groups, it was established that a prestigious department store in Berlin is already offering 2 brands of authentic English Christmas Pudding and a launch of this product would therefore be met by some competition.

Another question which could not be answered related to the estimated costs for TV, radio and newspaper advertisements. However, student 2 recognized that this information would be difficult to obtain from the internet.

Besides these unanswered questions, the following could be established:

The product Christmas Pudding was to be launched on to the German market not as a mass product aiming at every household, but one for the luxury end of the market. It was to be marketed as a typical English desert at Christmas. Taking the foodawareness of the average German customer into account, the product would not contain nuts (because of the existence of nut allergies in some customers), and one vegetarian version (without animal fats) would be for sale. There would also be the choice between a Christmas Pudding containing alcohol and one without, as well as a normal size and one miniature version as a taster and also aimed at children. After some lengthy discussion it was decided to sell a rum sauce in separate packaging, but attached to the Christmas Pudding itself. Other ideas for sauces, e.g., malt wine ("Glühwein" as well as "Eierlikőr"), whiskey and brandy were discussed but discarded. Information to be given on the packaging also caused some lengthy discussions. Which image should be given to the product, should it be branded as a traditional desert with roots in religious beliefs, should the history of Christmas Puddings be included, should the packaging carry information in German or German and English, etc? It was finally decided that the packaging should only carry the following information: The company name (Food for Thought), the English product name (Christmas Pudding), and some information about the connection between Christmas and Christmas Pudding. 
The prices for the two different sizes were decided and the food outlets agreed. Initially, the product was to be exported to Germany and its success would be closely monitored. Once it could be established on the German market, a factory in Germany would be either built or acquired in order to produce for the German market.

It is important to note that these conclusions were reached through discussion between different groups and synthesis of the given information. Group 1, as client and therefore employer of all the other groups, was the decision maker in this role-play. Whether they agreed to use the other groups' information or suggestions was entirely up to group 1.

Additional information was gathered which was not part of the initial questions. The process-oriented nature of the task allowed students to explore issues which developed during the project. Table 1 indicates that students expanded their work beyond the framework of their initial questions: Decisions were made regarding the ingredients of the product, preparation information on the product wrapping, and a short history of Christmas Puddings, i.e., its roots in religious beliefs.

Even though these questions did not present themselves initially, during the process of the development of the project they became important issues which were discussed and decided upon.

All participating students were familiar with the chosen product before the start of the project. They were also aware of seasonal specialties at Christmas in Germany. However, through this collaborative effort all students gained a much deeper understanding of both (Christmas specialties in Britain and Germany) and the problems a launch could bring. It seems therefore that all participants have acquired content. 
Table 1: Comparison between initial questions and reported outcomes (the original text can be found in appendix 1)

\begin{tabular}{|c|c|}
\hline $\begin{array}{l}\text { Initial questions for group's research }{ }^{8} \text { (week } 1 \text { of } \\
\text { project) }\end{array}$ & $\begin{array}{l}\text { Answers to questions (week } 3 \text { - group result + week } 4 \text { of project - individual } \\
\text { results) }\end{array}$ \\
\hline $\begin{array}{l}\text { Who are our competitors? - Are there different size } \\
\text { brands? How many? }\end{array}$ & $\begin{array}{l}\text { week 3:2 traditional English Christmas Puddings are already being sold in } \\
\text { KaDeWe (Fortnum \& Mason, Wilkin \& Sons, week 4, Stud 2: We have not received } \\
\text { enough information about our competitors, we do not know, how much competition } \\
\text { there is in this market and which are the largest competitors. }\end{array}$ \\
\hline $\begin{array}{l}\text { Which ingredients should we use in this market? for } \\
\text { example sherries or nuts }\end{array}$ & $\begin{array}{l}\text { week 3: Christmas Pudding (luxury) for vegetarians - without any animal } \\
\text { ingredients; typically English. - Without nuts (nut allergies) - one with alcohol and } \\
\text { one without }\end{array}$ \\
\hline $\begin{array}{l}\text { Which sauces should we use for this market? e.g., rum, } \\
\text { malted wine, egg liqueur? }\end{array}$ & week 3: Rum sauce is sold with our product \\
\hline $\begin{array}{l}\text { Other products which can be bought instead of } \\
\text { Christmas Pudding, e.g., cake, mince pies or biscuits }\end{array}$ & $\begin{array}{l}\text { week 4, stud. 1: Other products, which can be bought instead of Christmas Pudding. } \\
\text { e.g., cake, mince pies or biscuits }\end{array}$ \\
\hline How shall we call Christmas Pudding in German? & week $3+4$ : Christmas Pudding \\
\hline
\end{tabular}

\footnotetext{
${ }^{8}$ The table below is a translation of the student work which aimed to retain the structure of the original. The original punctuation was largely retained. See appendix 1 for original quotes in German.
} 


\begin{tabular}{|c|c|}
\hline What is the size of the market? & $\begin{array}{l}\text { week 4, Stud. 2: We also do not know the size of the market in the new } \\
\text { Bundesländer. In order to be successful these questions need to be answered. [...] } \\
\text { Regarding a few points as the size of the market, our colleagues forgot that we had } \\
\text { asked the questions. }\end{array}$ \\
\hline $\begin{array}{l}\text { Where can we sell Christmas Pudding? e.g., } \\
\text { supermarket or Christmas market? }\end{array}$ & $\begin{array}{l}\text { week 3: Christmas market, small sweet shop, Tengelmann und Kaufhof, Real - } \\
\text { week 4, stud. 2: I still do not know how products can be sold to supermarkets in } \\
\text { Germany, e.g., do we sell directly to the supermarkets or do we have to sell through } \\
\text { a trader? }\end{array}$ \\
\hline How much is a Christmas Pudding? & $\begin{array}{l}\text { week 3: offer } 2 \text { different Christmas Puddings } € 7,99 \text { and } € 3,99 \text { children Christmas } \\
\text { Pudding in small packages }\end{array}$ \\
\hline $\begin{array}{l}\text { How much money do we need for advertising? TV, } \\
\text { radio or newspapers etc. }\end{array}$ & $\begin{array}{l}\text { week 4, stud. 1: We do not know how much money we need for advertising. - week } \\
4, \text { stud. } 2 \text { : We also did not receive any information about the costs for different } \\
\text { types of advertising, if we want to sell this product in Germany we need to promote } \\
\text { it, for that we need information about the costs for advertising on radio or TV etc. I } \\
\text { believe that for a large part there was not enough information on the internet in } \\
\text { order to answer all our questions, e.g., the costs for advertising, perhaps we have to } \\
\text { ask the TV companies themselves how much that is. }\end{array}$ \\
\hline
\end{tabular}




\begin{tabular}{|c|c|}
\hline $\begin{array}{l}\text { How do we deliver our product to our customers? In } \\
\text { the future, shall we produce it in Germany? }\end{array}$ & $\begin{array}{l}\text { week 4, stud. 1: It could be expensive to export. If it is successful during this year, } \\
\text { we have to see, whether it is possible to produce it in Germany next year. - week } 4 \text {, } \\
\text { stud. 2: we do not have enough information about the distribution channels in } \\
\text { Germany. }\end{array}$ \\
\hline $\begin{array}{l}\text { we need information about the cultural differences } \\
\text { between Germany and England - e.g., taste. }\end{array}$ & $\begin{array}{l}\text { week 4, stud. 2: We do not know enough about the cultural differences in order to } \\
\text { say that this will not have a big effect on the launch of our product. [...] I do not } \\
\text { see big cultural problems, which would hinder the introduction of Christmas } \\
\text { Puddings in Germany. The Germans are rather willing/prepared to buy typical } \\
\text { English products, especially food. We saw that with KaDeWe, who already offer } \\
\text { two brands of Christmas Pudding. }\end{array}$ \\
\hline \multicolumn{2}{|c|}{ The following results developed during the project and were not part of the initial questions. } \\
\hline & week 4, stud 1: English Christmas Pudding company: 'Food for Thought!' \\
\hline
\end{tabular}


The comparison between the transcript of oral interaction and email communication can highlight where students encountered difficulties. The following section looks at how students $1+2$ attempted to solve a grammatical problem occurring during the process of writing an email message to their colleagues.

\subsection{Solving grammatical problems}

The transcript of student discussions highlights their grammatical problems, e.g., the application of the correct tense (see Table 2 below), which manifests itself here in the verb "antworten" even though the correct verb here would be "beantworten". Both are translations of "to answer, to reply". The group is aware that they are writing their text in perfect tense, which consists of a form of to have or to be and the past participle. The past participle is presenting a problem here: Past participles usually gain the prefix - ge- before the verb stem and regular verbs end in -(e)t- while irregular verbs end in -en- . Student 2 uses the verb first, hesitates, is obviously unsure about the correct ending and paraphrases her sentence, avoiding the problem. Student 1 replies with just the stem of the verb, antwort. Student 2 corrects (?) with/ names the infinitive, antworten. Student 1 suggests to write the verb with the regular past participle ending, antwortet, to which student 2 agrees. After a few more exchanges, they both simultaneously remember the prefix for the past participle and say geantwortet.

This particular problem was solved successfully, even though a slightly incorrect phrase was used ${ }^{9}$, in this context a minor error (lexical) since they could both successfully come to the correct conclusion for the grammatical problem.

A few lines later, they encounter a new problem, that of a preposition followed by the correct case and the noun in plural. After discussing several options, they arrive at the correct conclusion (see below).

\footnotetext{
${ }^{9}$ They intended to express either 'Wir haben auf die Fragen geantwortet' or 'Wir haben die Fragen beantwortet'.
} 
The transcript in comparison with the end-product, here an email, shows clearly where problems occur and how students are going through the motions of solving them. This is less an example of peer-tutoring but of collaborative solving of problems. Through team work students overcome encountered difficulties. 
Table 2 - grammatical problem

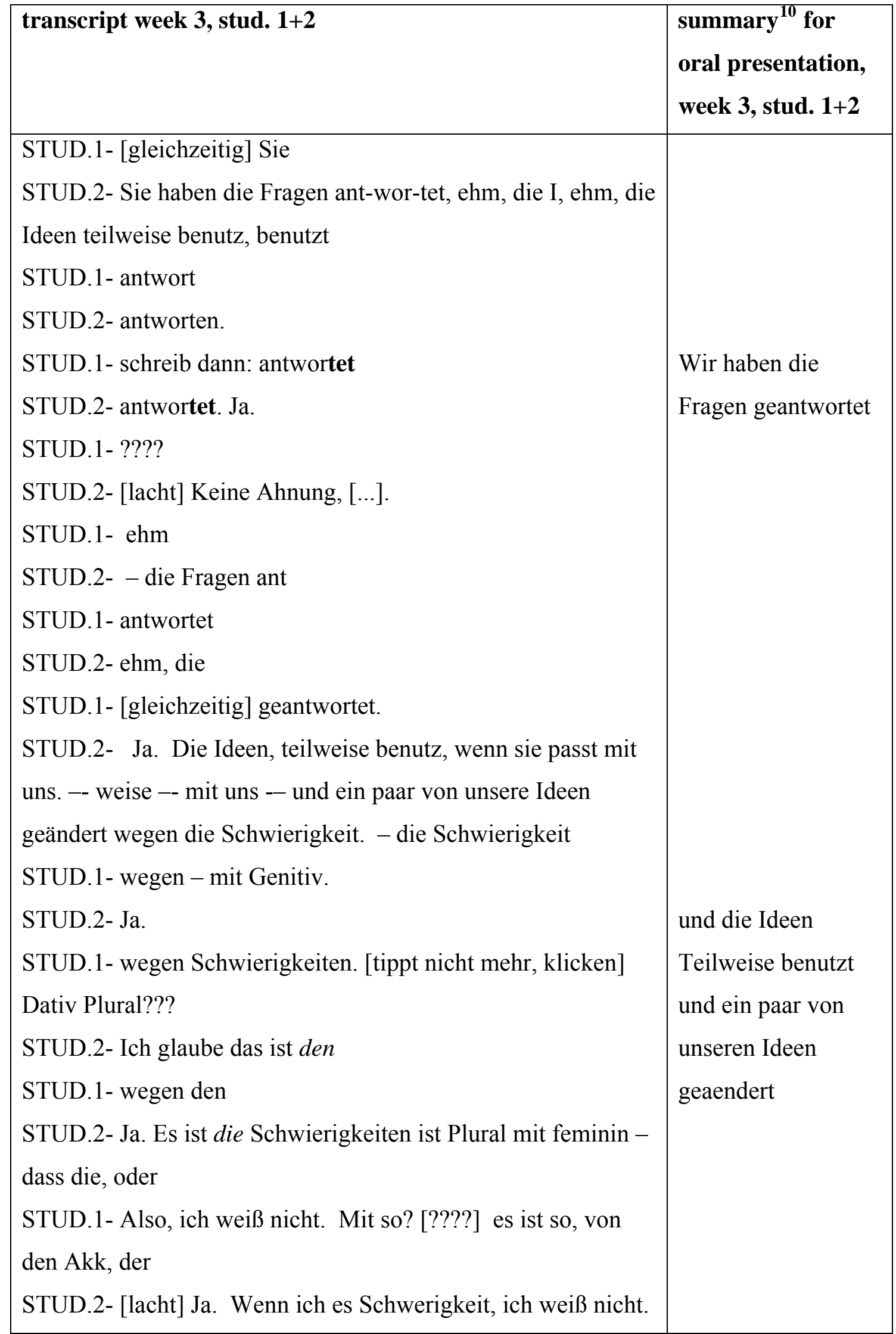

${ }^{10}$ printed verbatim. However, the sentence has been matched against the matching utterances of the session's transcript. 
STUD.1- Schwierigkeiten, Plural.

STUD.2- Ja. So. Die.

STUD.1- [gleichzeitig] die

STUD.2- Und dann es geht: die, den, das, den.

STUD.1- [unverständlich]

STUD.2- das ist für Neutrum und

STUD.1- maskulin. - OK. Dann, das haben wir schon gemacht.

Das war alles, oder?

wegen der

Schwierigkeiten

The example above (table 2) highlights another point, which is worth noting: The flow of information or the type of communication, which shall be looked at in the next section.

\subsection{Information flow}

The transcription of this group's oral interaction in the computer room shows a form of communication, which is often difficult to understand on its own. The students do not communicate in a manner usually associated with communication models, i.e., transferring information from a sender to a receiver and vice versa. Instead, the computer screen is an integral part of the oral communication between the students and fills the gaps which are left by the utterances recorded on tape. This fact was also reflected in the body language of the students in this group. Student 1 typed all the messages and faced mainly the computer screen. Student 2 sat to the left and faced the screen too. Student 2 did not want to use the computer for research purposes, even though this was encouraged, but checked the partner's spelling, dictated email addresses, checked their progress against a paper version of the task, and read incoming emails on screen. The computer screen with the displayed information of either incoming or outgoing emails and the word document produced by student 1 has been the third constituent part of the interaction between students $1+2$.

This phenomenon needs to be monitored closely and compared with the other groups' interaction. If this type of collaborative work is set up to support second language 
acquisition, the extensive use of incomplete sentences may hinder the practice and development of more sophisticated sentence structures and may have a detrimental effect on second language use. However, even though the oral communication between these two students within this group is largely characterized by the exchange of fragments of sentences, this fact did not have any apparent negative effect on the meaning communicated.

However, on other occasions during oral interaction, students continue or finish each other's sentences and the meaning becomes immediately clear, when the text is read continuously, irrespective of who actually spoke (section in italics below). In search for the word "preparation", student 1 suggests the term recipe, but corrects himself immediately, recognising that the meaning differs. Student 2 replies that when the product is sold, all ingredients have already been put together, but that the instructions for preparation have to include how to heat or cook the product. Here, one student finishes the sentence of the other, hereby making perfect sense.

\begin{tabular}{|l|l|}
\hline $\begin{array}{l}\text { transcript week } 2 \\
\text { Discussion about which elements of the product } \\
\text { should be translated into German }\end{array}$ & $\begin{array}{l}\text { Email from stud 1+2 to all } \\
\text { other groups (week 2, 10:33) }\end{array}$ \\
\hline STUD.2- Ja, so alle die Zutaten & \\
STUD.1- Ja. & Alle Zutaten und die \\
STUD.2- Vielleicht sagen: alle Zutaten sollte in & Vorbereitungsprozesse ${ }^{11}$ \\
Deutsch sein, und wenn wir [stud.1 tippt] und, ehm, & sollten auf Deutsch sein. \\
Vorbereitungs & \\
STUD.1- alle Zutaten und Rezepte, Rezepte, ne, das & \\
ist nicht das gleiche. & \\
STUD.2- Ne, wenn wir verkaufen ist das schon & \\
gemacht, aber wir muessen sagen, & \\
STUD.1- wie man es kochen soll & \\
STUD.2- Ja, so & \\
STUD.1- Vorbereitung, ja, so Vorbereitungs---- & \\
prozesse. &
\end{tabular}

${ }^{11}$ They obviously mean "Anleitung für die Zubereitung" 
STUD.2- Informationen, oder so was.

STUD.1- If I - Vorbereitung --- prozesse?

STUD.2- mmh. --- Sollte in Deutsch sein

Doch werden wir es

STUD.1- auf Deutsch sein - ehm, wir hoffen, wir

werden es, so Christmas Pudding nennen, oder?

"Christmas Pudding" nennen

- muessen wir "Christmas

STUD.2- Ja.

Pudding" nicht uebersetzen.

This section also shows how students negotiate meaning while looking for the appropriate vocabulary. These students are in tune with each other and both are aware of which concept they are referring to since the third element of their communicative interaction, the text on the computer screen, complements their talk (see above). Together, they are trying to phrase the information for an email message to be sent to their fellow students. Taking the above example in a wider context (the lines before and after the section in italics), they are looking for the word "preparation" as a heading to be included on the product packaging. Preparation can have different translations in German "Vorbereitung" (as in preparation for an exam) und "Zubereitung" (as in preparation of a meal). They both cannot think of the appropriate translation "Zubereitung", but narrow it down through similar terms "Vorbereitung", and "Rezept". Student 1 is aware that the latter, recipe, carries a different meaning. In their email message to the other groups they settle on "Vorbereitungsprozesse" (preparation processes), a close, but not fully appropriate term.

Once the tutor approached the group with questions or comments, the oral communication between students and tutor took place in the familiar form of more complete sentences. While working on their own as a pair, the context of the student interaction is well defined through their utterances and the text on screen. Once the tutor enters the communication, the context needs to be established in order to aid the communication well enough to make the answer unambiguous. Below, student 2 expresses the opinion, that a discussion about the usefulness of a particular product for this project is not relevant. Once in employment with a company which wants to export a specific product, employees will have to deal with that request. It would be unrealistic to discard the idea immediately without having checked the feasibility of exporting the product. 
The concept expressed here is more complex and is expressed to the tutor who had just joined the group. Appropriately, student 2 gave her comment in complete sentences. 


\begin{tabular}{|c|c|}
\hline $\begin{array}{l}\text { Example: } \\
\text { transcript session 3, group 1, p. } 7\end{array}$ & Translation of meaning (CL) \\
\hline $\begin{array}{l}\text { Stud. 2- Das Produkt ist eigentlich } \\
\text { nicht so wichtig, weil wenn wir für } \\
\text { eine Firma gearbeiten, das } \\
\text { Christmas Puddings verkauft, dann } \\
\text { ist es egal, was die richtige Produkt } \\
\text { ist oder nicht. Wir müssen diese } \\
\text { Produkt nehmen, weil es ist die } \\
\text { einzige von diese Firma. }\end{array}$ & $\begin{array}{l}\text { Stud. 2- The product is not really that } \\
\text { important, because if we work for a } \\
\text { company which sells Christmas } \\
\text { Puddings, then it does not matter which is } \\
\text { the right product. }\end{array}$ \\
\hline CL- Richtig. & CL- That's right. \\
\hline $\begin{array}{l}\text { Stud. 2- So wir können nicht } \\
\text { wirklich sagen, das Produkt ist } \\
\text { nicht so gut, weil, wenn wir in eine } \\
\text { Christmas Pudding Firm arbeiten, } \\
\text { dann haben wir nur Christmas } \\
\text { Puddings }\end{array}$ & $\begin{array}{l}\text { Stud.2- Therefore we cannot really say } \\
\text { that the product is not that good, because } \\
\text { if we work in a Christmas Pudding } \\
\text { company, we will have only Christmas } \\
\text { Puddings. }\end{array}$ \\
\hline
\end{tabular}

The email messages themselves also mainly reflect a more composed character, as can be seen in the example below. Communication with the other groups needs to ensure that the relevant information is transmitted. Therefore, sentences are complete and linked logically. Questions are asked clearly in order to facilitate that colleagues can research the needed information.

\begin{tabular}{|l|l|}
\hline $\begin{array}{l}\text { Sent: } \\
\text { 19/11/01 10:05 }\end{array}$ & \\
\hline $\begin{array}{l}\text { Hallo zusammen, } \\
\text { Wir moechten unsere Marketingstrategie } \\
\text { klaren. Daher brauchen wir Information }\end{array}$ & $\begin{array}{l}\text { Hallo everybody, } \\
\text { We want to decide on our marketing } \\
\text { strategy. Therefore we need information }\end{array}$ \\
\hline
\end{tabular}




\begin{tabular}{|c|c|}
\hline $\begin{array}{l}\text { ueber Logistiks z.B. wo sollen wir unsere } \\
\text { Produkte verkaufen? - Supermaerkten, } \\
\text { Weihnachtsmaerkten usw. Wie sollen wir } \\
\text { unsere Produkte nach Deutschland } \\
\text { versenden? Z.B per Luft, Fracht usw. Wir } \\
\text { viel kosten die verschiedene Methoden? } \\
{[\ldots]}\end{array}$ & $\begin{array}{l}\text { about logistics, e.g., where shall we sell } \\
\text { our products? - supermarkets, Christmas } \\
\text { markets etc. How shall we send our } \\
\text { products to Germany? e.g., by air mail, } \\
\text { via land? How much do the different } \\
\text { methods cost? } \\
\text { [translation by CL] }\end{array}$ \\
\hline
\end{tabular}

The last point to look briefly at in this paper is the production of a longer text, largely written in bullet points, which is intended to aid the oral presentation of results.

During week 3 students prepared and presented their group's results of the project.

\subsection{Non-linear composition of text}

The transcript of session 3 shows that the sequence of points for the oral presentation did not develop in a linear process. Students firstly checked the task for the session, which was to describe the development of the project (1), name the results, i.e., the marketing strategy (2). Reference should be made to their knowledge of cultural and/or economic differences between the UK and the target market (3). Finally, students were asked to name possible difficulties for the introduction of the product (4) and outline possible solutions to overcome those difficulties (5).

Group 1 chose to follow the brief strictly in its outline for the oral presentation. All points were presented sequentially, only point 3 was omitted without explanation. The transcript reveals that it had been discussed. Student 2 comments that she does not know any answer to this question.

Even though the sequence of the brief is mirrored in the sequence of the oral presentation prompts, the transcript shows the sequence of discussion and development of the presentation prompts differs: After the initial clarification of the brief, the task was fulfilled in the following order: points $4,1,2,5$, briefly 3 , and 5 .

Further analysis of this group's and the other groups' work may shed more light on the pattern of communication and its effect on the language that is produced. 


\subsection{Student evaluation}

In their own perception ${ }^{12}$, both students saw advantages for their language practice within the framework of the electronic role-play. Student 1 commented $^{13}$ that he had had the opportunity to speak and write more than he normally has in the traditional classroom. He recognized that practice opportunities normally have to be shared between 10 students while during the computer class only these 2 students could make full use of the practice opportunities within a 2-hour-class. Student 2 draws a comparison to the stay abroad where more opportunities to speak and (to be corrected by native-speakers) exist. However, she experienced the lack of opportunities to write while she was abroad as a disadvantage. This aspect of the computer class, having to write summaries which are corrected by the tutor, was seen as positive, even though she refers to writing German on the computer as a difficult task in general, since some German language characters, e.g., Umlaut are difficult to type. However, student 2 did not make use of the opportunity to practise writing during weeks 1-3. She only typed the final obligatory summary herself.

\section{Conclusion}

Even though the methodological approach had to be modified and technologically simplified, it sufficed to extract and observe several points regarding the acquisition of content, focus on language form, as well as to highlight working patterns within a computer-assisted learning framework. Some of the initial assumptions regarding the usefulness of this research approach could therefore be verified.

The results of one group's work show that the electronic role-play can facilitate the acquisition of content. Furthermore, observations of the students' interactions show that the oral communication between the two partners can be fragmented and on its own difficult to comprehend. However, it is apparent that the computer screen is a constituent part of the communication that complements the oral interaction.

The results of this group show that the composition of longer text develops in a nonlinear fashion.

As mentioned in the introduction to this article, Chapelle (2001) names several criteria for appropriate CALL task design, including focus on language form. As

\footnotetext{
${ }^{12}$ for a transcript in German - see appendix

${ }^{13}$ during the final discussion among all participants during week 4.
} 
shown above collaborative efforts led the participants to deal with and solve several grammatical problems. Specific focus on language form is evident which is the result of language practice in an authentic subject-specific situation.

The results presented here are findings of a larger, complex project. Further research will reveal whether these results can be indicative for other learners as well.

A further step will be a cross-analysis of language output amongst different groups participating in the same project. 
Appendix 1 -- Table 1: Comparison between initial questions and reported outcomes

\begin{tabular}{|c|c|}
\hline $\begin{array}{l}\text { Initial questions for group's research }{ }^{14} \text { (week } 1 \text { of } \\
\text { project) }\end{array}$ & Answers to questions (week 3 - group result +4 of project - individual results) \\
\hline $\begin{array}{l}\text { Wer sind unsere Wettbewerb? - gibt es verschiedene } \\
\text { groesse Marken? und wie viel? }\end{array}$ & $\begin{array}{l}\text { week 3:Es werden bereits } 2 \text { traditionelle englische Marken fuer Christmas Pudding } \\
\text { im KaDeWe gefuehrt (Fortnum \& Mason, Wilkin \& Sons, week 4, Stud 2: Wir haben } \\
\text { aber nicht genug Information ueber unsere Wettbewerb bekommen, wir wissen nicht } \\
\text { wie viel Konkurrenz es in diesem Markt schon gibt und wer die groesste konkurrenten } \\
\text { sind. }\end{array}$ \\
\hline $\begin{array}{l}\text { Was fuer Zutaten sollen wir in diesem Markt benutzen? } \\
\text { z.B. Kirche oder Nuessen }\end{array}$ & $\begin{array}{l}\text { week 3: Christmas Pudding (Luxus) fuer Vegitarischen Leute - ohne Tierischezutaten; } \\
\text { Typisch Englisch.- Ohne Nuesse (Nusseallergien) - - ein mit Alkohol und ein ohne } \\
\text { Alkohol (alkohol frei) }\end{array}$ \\
\hline $\begin{array}{l}\text { Was fuer Sossen sollen wir in diesem Markt benutzen? } \\
\text { z.B. Rum oder Gluehwein, Eierliqor }\end{array}$ & week 3: Rum Sosse wird zusammen mit unserem Produkte gekauft \\
\hline Wie sollen wir Christmas Pudding auf Deutsch nennen? & week $3+4$ : Christmas Pudding \\
\hline
\end{tabular}

\footnotetext{
${ }^{14}$ All quotes of student work are printed verbatim. In order to utilise space, some text (italic) was written by CL, based on student results.
} 


\begin{tabular}{|l|l|}
\hline Wie groesst ist der Markt? & $\begin{array}{l}\text { week 4, Stud. 2: Wir wissen auch nicht wie groess der Markt in den neuen } \\
\text { Busndelaendern ist, um erfolgreich zu sein mussen wir solche sachen erklaeren. } \\
{[\ldots] \text { Aber bei ein Paar Punkte wie die Marktgroesse haben unsere Kollegen vergessen }} \\
\text { das wir gefragt haben. }\end{array}$ \\
\hline $\begin{array}{l}\text { Wo koennen wir Christmas Pudding verkaufen? z.B. } \\
\text { Supermarkt, Weihnachtsmarkt }\end{array}$ & $\begin{array}{l}\text { week 3: Weihnachtsmarkt, kleine Sussigkeitsladen, Tengelmann und Kaufhof, Real - } \\
\text { week 4, stud. 2: Ich weiss immer noch nicht wie man Produkte an der Supermaerkte } \\
\text { in Deutschland kaufen kann, z.B. ob wir direct an der Supermaerkte kaufen oder ob } \\
\text { durch eine Haendler kaufen muss. }\end{array}$ \\
\hline Was kostet ein Christmas Pudding? & $\begin{array}{l}\text { week 3: 2 verschiedene Christmas Puddings anbieten } € 7,99 \text { und } € 3,99 \text { Kinder } \\
\text { Christmas Pudding in kleine Paeckchen }\end{array}$ \\
\hline
\end{tabular}




\begin{tabular}{|c|c|}
\hline $\begin{array}{l}\text { Wie viel Geld brauchen wir fuer Werbungen? TV, } \\
\text { Radio oder Zeitungen usw. }\end{array}$ & $\begin{array}{l}\text { week 4, stud. 1: Wir wissen nicht wie viel Geld wir fuer Werbung brauchen. - week 4, } \\
\text { stud. 2: Wir haben auch kein Information bekommen ueber wie viel verschieden arten } \\
\text { von Werbungen kosten, wenn wir diesem Produkt in Deutschland verkaufen will wir } \\
\text { muss es Promotieren, dafuer brauchen wir Information ueber wie viel es kostet fuer } \\
\text { Werbungen im Radio oder im Fernsehen usw. Ich glaube dass zum groessen Teil gab } \\
\text { es nicht genug Information im Internet alle unsere Fragen zu antworten, z.B. die } \\
\text { Kosten von Werbungen, vielleicht muessen wir die Fernsehsendung selbst fragen wie } \\
\text { viel so was kostet. }\end{array}$ \\
\hline $\begin{array}{l}\text { Wie werden wir den Produkt an unseren Kunden } \\
\text { liefern? Sollen wir im Zukunft es in Deutschland } \\
\text { herstellen? }\end{array}$ & $\begin{array}{l}\text { week 4, stud. 1: Es koennte teuer zu exportieren. Wenn es dieses Jahr erfolgreich ist, } \\
\text { muessen wir sehen, ob es moeglich naechstes Jahr in Deutschland zu herstellen ist. - } \\
\text { week 4, stud. 2: wir haben nicht genug Information ueber die Verteilungskanaele in } \\
\text { Deutschland. }\end{array}$ \\
\hline
\end{tabular}


The following results developed during the project and were not part of the initial questions.

week 3: Verpackung: Zutaten-Wie man es vorbereiten soll-Unsere Firmennamen-Eine

kleine Geschichte ueber die Verbindung zwischen Weihnacht und Christmas

Puddings (Englisch und Deutsch)-Gewicht usw.

week 4, stud 1: englische Christmas Puddings Firma: 'Food for Thought!' 


\section{Appendix 2}

Stud. 1 - Ich glaube, dass ich so mehr - Deutsch gesprochen und geschrieben - habe, als wie so die gleiche Zeit in der Klasse.

Stud. 2 - Ja.

Stud. 1 - Normalerweise gibt es 10 Leute in unserer Klasse. Wir müssen - ja - wir teilen - so - die 2 Stunden. Aber, so diese Computerklasse bleiben, es gab hier also Emma und ich zusammen, wir haben so, wir haben eine halbe Stunde nur auf Deutsch gesprochen. Und dann diese Bericht heute geschrieben. Das war mehr so ich habe es besser als, als wie (?) mehr Deutsch, mehr Deutsch, eh, eh ...

CL - praktiziert?

Stud. 1 - Ja. Praktiziert. That's it. (?)

Stud. 2 - Das Problem mit unsere Kursen, diesen, ja, in Deutschland ist das mehr, wirklich mehr Chance, wir emh, wir haben immer die Chance, es gibt so fast keine Chance, was schriftlich zu machen, das dann korrigiert werden. So, wenn man spricht mit andere Leute, die sagen, so - wenn es wirklich falsch ist, die sagen was. Und auch, so, wenn man hört andere Leute, man, be- kriegt so Tipps und so weiter, von was die sagen immer. Dann man sagt so was, wenn man es sagen will. Und mit schriftliche Sachen gibt's nicht so viel. So, wir haben unsere Prüfungen schriftlich gemacht, aber wir haben die - nie wieder gesehen. Und bei meiner Arbeit habe ich auch kein Deutsch geschrieben. Und deshalb gibt's diese so Angst für diese schriftliche Teil von unserer Dissertation.

CL - Und glaubst du, dass du - in diesem Zusammenhang, dir diese Computerklasse geholfen hat?

Stud. 2 - Ja, ein bisschen. So es hat die - so heute und letzte Woche haben wir die Möglichkeit gehabt, was schriftlich zu machen. Ich finde es ziemlich schwerig am Computer was Deutsch, emh, zu schreiben, weil es mit die Umlaut und so weiter, man kann nicht so, emh, schreiben, wie man es wirklich schriftlich macht. Aber, ja. Es hat geholfen.

\section{References}

Chambers, A. (2001) "Introduction" In: Chambers, A., Davies, G. (2001) ICT and Language Learning. A European Perspective. Lisse: Swets \& Zeitlinger. 
Chapelle, C. (2001) Computer Applications in Second Language Acquisition, Cambridge: Cambridge University Press.

Chapelle, C. (2000) 'Is network-based learning CALL?' In: Warschauer, M. and R. Kern (eds.) Network-based language teaching: Concepts and Practice . Cambridge: CUP.

Chapelle, C. (1997) 'CALL in the year 2000: Still in search of research paradigms?' in Language Learning \& Technology, Vol 1 (1): 19-43.

http://1t.msu.edu/vol1num1/chapelle/default.html

Davies, G. (2001) "New Technologies and Language Learning: A suitable subject for research" In: Chambers, A., Davies, G. (2001) ICT and Language Learning. A European Perspective. Lisse: Swets \& Zeitlinger.

Delcloque, P. (2001) 'What does the history of CALL teach us?' http://www.historyof-call.org//

Ess, C. (ed.) (2001) Culture, Technology, Communication. Towards an Intercultural Global Village. New York: State University of New York Press.

Ess, C. (ed.) (1996) Philosophical Perspectives on Computer-mediated Communication. New York: State University of New York Press.

Leahy, C. (2001) "Electronic role-play as a means for construction of knowledge online" in conference proceedings of the International conference 'CALL \& The Challenge of Change' in Exeter, Sept. 2001, Elm Bank Publications, pp.185-191.

Levy, M. (2001) 'Coherence and direction in CALL research: Comparative Designs' CALL \& The Challenge of Change in Exeter, Sept. 2001, Elm Bank Publications, pp.5-13.

Levy, M. (2000) 'Scope, goals and methods in CALL research: questions of coherence and autonomy'. ReCALL; Vol.12 (2), pp. 170-195. 
Levy, M. (1997) Computer-Assisted Language Learning: Context and Conceptualization. Oxford: Clarendon Press.

Murray, D. (2000) 'Changing Technologies, changing literacy communities?'

Language Learning and Technology, Vol. 4, No. 2, pp. 43-58 .

http://ltt.msu.edu/default.html

Papert, S., Harel, I. (eds.) (1993) (second edition). Constructionism, Norwood (NY, USA): Ablex Publishing Corporation.

Warschauer, M. (2001) 'Language, identity and the Internet.' MOTS PLURIELS, No

19, October 2001 http://www.arts.uwa.edu.au/MotsPluriels/MP1901mw.html

Warschauer, M., Kern, R. (eds.) (2000) Network-based Language Teaching: Concepts and Practice. Cambridge: CUP.

Warschauer, M. (1999) Electronic Literacies. Language, Culture and Power in Online Education. Mahwah, NJ: Lawrence Erlbaum Associates. 